\title{
Pemanfaatan Permainan Bahasa Menjadi Produk Usaha Kaos Berbasis Bisnis Kata di Kelompok Karang Taruna Desa Parangargo Kecamatan Wagir Kabupaten Malang untuk Mendukung Ekonomi Kreatif
}

\author{
Kingkin Puput Kinanti1 ${ }^{1}$, Endang Setiyo Astuti ${ }^{2}$, Dwi Ulfa Nurdahlia ${ }^{3}$ \\ ${ }^{123)}$ IKIP Budi Utomo, Malang, Jawa Timur, Indonesia \\ ${ }^{1}$ Email: kingkinkinanti13@yahoo.co.id \\ ${ }^{2}$ Email: mynameisendang@gmail.com \\ ${ }^{3}$ Email: dwiulfa@gmail.com
}

\begin{abstract}
The activities of Society Partnership Program (PKM) was carried out together with the youth organization of Karang Taruna MAATOON in Parangargo village, Wagir sub district, Malang Regency. The purposes of the activities are 1) to empower the youth to become entrepreneurs and get involved in developing creative economy, 2) to develop the skill of designing words, phrases, and sentences used to produce saleable word-based T-shirts, like Dagadu and Joger, 3) to facilitate the Karang Taruna in producing and marketing the products. In order to achieve the purposes, on the aspects of production and management, some trainings and workshops have been already done, such as training of word designing through Corel Draw application and workshop of finance management and digital marketing. These activities of Society Partnership Program (PKM) were done in stages, namely preparation, program planning, implementation, and evaluation.
\end{abstract}

Keywords: youth organization, T-shirt, enterpreneurs.

\section{PENDAHULUAN}

Ekonomi kreatif merupakan konsep ekonomi yang sedang berkembang di negara Indonesia. Konsep ini dimulai pada tahun 2006 ketika Presiden Susilo Bambang Yudhoyono mengintruksikan untuk mengembangkan ekonomi kreatif. Konsep ekonomi kreatif itu sendiri merupakan konsep yang mengutamakan ide dan gagasan sumber daya manusia (SDM) sebagai faktor produksi utama. Kemampuan berkreativitas dan berinovasi dari SDM menjadi ujung tombak dari ekonomi kreatif.

Bahasa sebagai produk dari manusia merupakan sumber ekonomi kreatif. Beberapa brand terkenal di Indonesia seperti Dagadu, Yajugaya, dan Kaos Gurita berhasil memanfaatkan bahasa sebagai produk usaha yang menjanjikan. Kreativitas merangkai kata yang menarik dan khas terbukti mampu meningkatkan kesejahteraan.
Bahasa yang digunakan dalam produk-produk tersebut adalah pemanfaatan permainan bahasa. Permainan bahasa dalam istilah ilmu linguistik merupakan bentuk penggunaan bahasa yang tidak semestinya. Terjadi penyimpangan seperti penyimpangan fonologis, gramatikal, kekacauan hubungan bentuk dan makna, dan bermacam-macam pelanggaran yang bersifat pragmatis yang dimaksudkan untuk mencapai bermacam-macam tujuan, yaitu melucu, mengkritik, menasihati, melarang dan sebagainya. (Wijana, 2010:248). Sebagai contoh penggunaan permainan bahasa dalam kaos Dagadu adalah kalimat yang diaplikasikan dalam kaos "Abdi dalem, Keep Kalem Without Helem". Pada kalimat tersebut terdapat permainan bahasa yaitu permainan pada bunyi dalem, kalem, dan helem. 
Pemanfaatan kreativitas menciptakan permainan bahasa merupakan potensi besar yang dapat dikembangkan kepada masyarakat. Pemberdayaan melalui ekonomi kreatif dirasa penting dilakukan. Pemuda dan organisasi pemuda merupakan komunitas yang dekat dengan industri kreatif.

Salah satu organisasi pemuda yaitu Karang Taruna Desa Parangargo Kecamatan Wagir bernama "MAATOON" merupakan organisasi pemuda yang memiliki antusias yang besar dalam mengembangkan kemandirian melalui kegiatan usaha yang produktif. Terbukti dari salah satu program kegiatan Karang Taruna yaitu penyelenggaraan kerja sama pembukaan usaha dengan instansi dan perusahaan.

Karang Taruna "MAATOON" merupakan karang taruna yang berdiri sejak tahun 2006. Selama perjalanannya, karang taruna tersebut tidak berjalan aktif. Kegiatan hanya dilakukan pada saat perayaan hari besar seperti kegiatan Agustusan. Pada tahun 2017, setelah pergantian ketua, organisasi ini kembali aktif dengan penyusunan program kerja yang lebih sistematis.

\section{Karang Taruna "MAATOON"} diketuai oleh pemuda bernama Veldy yang beranggotakan 29 pemuda dan pemudi. Kata "MAATOON" itu sendiri merupakan istilah dari bahasa Jawa yang berarti Mapan. Diharapkan organisasi pemuda ini dapat memberikan kemapanan bagi anggota dan masyarakat Desa Parangargo.

Salah satu program kerja Karang Taruna "MAATOON" adalah membuka usaha kaos sablon. Berdasarkan wawancara dengan ketua Karang Taruna, pada awal tahun 2018, Karang Taruna "MAATOON" telah mendapatkan dana pemerintah melalui anggaran desa untuk usaha pembuatan kaos sablon. Dana tersebut telah dibelanjakan salah satunya adalah alat untuk mencetak atau alat sablon kaos. Saat ini Karang Taruna "MAATOON" memiliki 2 unit alat sablon kaos manual. Hanya saja kegiatan usaha sablon kaos tersebut belum dapat direalisasikan kegiatannya hingga sekarang karena keterbatasan keterampilan SDM dan kurangnya alat untuk kegiatan usaha kaos sablon.

Beberapa hal yang menjadi permasalahan adalah,

1) Pemuda pemudi tidak memiliki ide untuk mengembangkan usaha kaos sablon yang bernilai jual. Pembuatan kaos sablon yang hanya memanfaatkan gambar-gambar kurang menonjolkan ciri khas dalam produk yang akan ditawarkan.

2) Lemahnya SDM dalam keterampilan desain

3) Kurangnya peralatan penunjang sablon

4) Lemahnya SDM dalam manajemen keuangan dan pemasaran.

\section{METODE PELAKSANAAN}

Berdasarkan permasalahanpermasalahan yang telah dirumuskan, akan ditawarkan solusi melalui Program Kemitraan Masyarakat. Program PKM ini akan dilaksanakan sebagai upaya pemberdayaan kelompok Karang Taruna dalam bidang kewirausahaan melalui pelatihan kewirausahaan untuk membentuk wirausahawan baru. Metode pelaksanaan program yaitu, 1) survey dan diskusi rencana usaha, 2) pelatihan motivasi usaha, 3) pelatihan menciptakan permainan bahasa 4) pelatihan desain dengan memanfaatkan corel draw, 5) pelatihan pemasaran digital, 6) pelatihan manajemen keuangan, 7) pelatihan dan pendampingan produksi dengan menggunakan teknologi alat sablon digital 8) uji coba produk dan pemasaran, dan 9) evaluasi produk. 
HASIL DAN PEMBAHASAN

Hasil Pengabdian Masyarakat

Hasil pengabdian masyarakat ini akan berdampak pada mitra yaitu:

1. Meningkatkan pengetahuan, pemahaman, serta keterampilan mitra dalam bidang penciptaan permainan bahasa, meningkatkan kemampuan desain dengan corel draw, meningkatkan pemahaman dalam manajemen keuangan, dan pemasaran digital.

2. Meningkatkan literasi pemuda/pemudi anggota Karang Taruna dengan permainan bahasa yang diaplikasikan dalam kaos.

3. Mengadakan teknologi mesin sablon, yaitu adanya mesin sablon digital untuk keperluan produksi kaos.

4. Menghasilkan wirausahawan baru di bidang industri kreatif.

Berdasarkan permasalahan yang telah dianalisis maka tim pengabdi melaksanakan program sesuai dengan metode yang telah

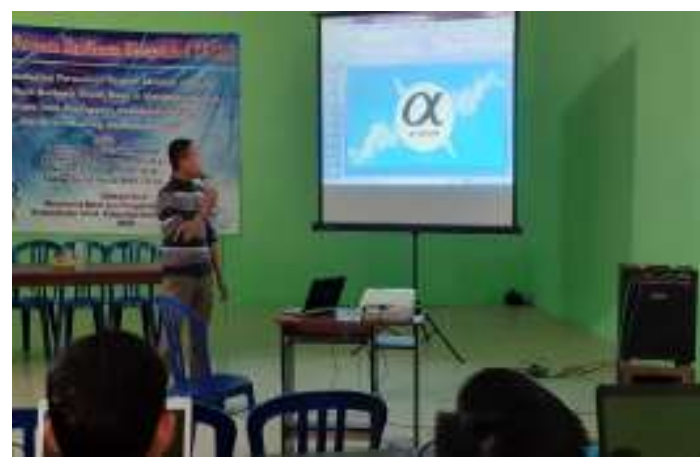

direncanakan. Adapun hasilnya sebagai berikut.

\section{a) Hasil Pelatihan motivasi} kewirausahaan

Kegiatan ini dilakukan dalam bentuk pelatihan motivasi usaha dengan mendatangkan narasumber yang berpengalaman dan telah sukses berwirausaha. Pemateri yang diundang adalah seorang wirausahawan muda dalam bidang industri kreatif di Kota Malang yaitu saudara Sofyan Alfarisi yang merupakan pengusaha kaos sablon lukis. Kegiatan dilaksanakan pada tanggal 27 April 2019. Kegiatan dilaksanakan melalui diskusi interaktif untuk menumbuhkan semangat baru dalam berwirausaha. Dalam kegiatan ini peserta terihat sangat antuasias mengikuti pelatihan. Hal ini terlihat saat beberapa peserta bertanya kepada narasumber. Adapun gambar kegiatan dalam dilihat pada Gambar 1.

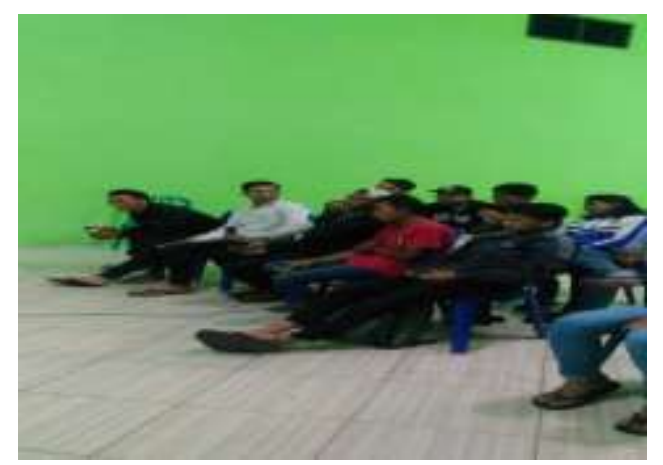

Gambar 1. Pelatihan motivasi usaha yang disampaikan oleh wirausahawan muda di bidang usaha kaos sablon (doc pribadi)

b) Pelatihan Penciptaan Permainan Bahasa sebagai Produk Utama Brand

Kegiatan ini dilakukan dalam bentuk diskusi interaktif dengan tim pengabdi yang merupakan dosen Pendidikan Bahasa dan Sastra Indonesia dan dosen Prodi Pendidikan Bahasa Inggris. Kegiatan pelatihan dilakukan untuk memberikan pemahaman serta melatihan keterampilan menciptakan bahasa yang menarik, khas, dan bernilai jual. Kegiatan dilaksanakan pada tanggal 30 April 2019. Dalam kegiatan ini peserta diberi pemahaman menganai teori permainan bahasa menurut ilmu bahasa serta tips dan trik mengenai cara menciptakan permainan bahasa. 
Peserta terlibat aktif dalam kegiatan terlihat pada saat peserta berlatih menciptakan permainan bahasa. Adapun dokumentasi kegiatan dalam dilihat pada Gambar 2.

c) Pelatihan Desain memanfaatkan Corel Draw

Desain merupakan komponen utama dalam memroduksi kaos setelah permainan bahasa sehingga pelatihan desain sangat diperlukan oleh mitra. Pelatihan dilakukan untuk memberi bekal kepada peserta dalam mendesain kaos. Aplikasi yang digunakan adalah corel Draw. Kegiatan ini dilakukan bekerjasama dengan narasumber yang ahli di bidang desain yaitu saudara Rizal. Kegiatan pelatihan dilaksanakan pada tanggal 4 Mei 2019. Adapun dokumentasi kegiatan dapat dilihat pada Gambar 3.

d) Pelatihan Manajemen Keuangan

Pelatihan manajemen keuangan diperlukan untuk dapat membuat laporan keuangan yang benar sehingga kelompok memiliki kemampuan mengelola keuangan. Kegiatan ini dilakukan pada tanggal 16 Mei 2019. Adapun dokumentasi kegiatan dapat dilihat pada Gambar4

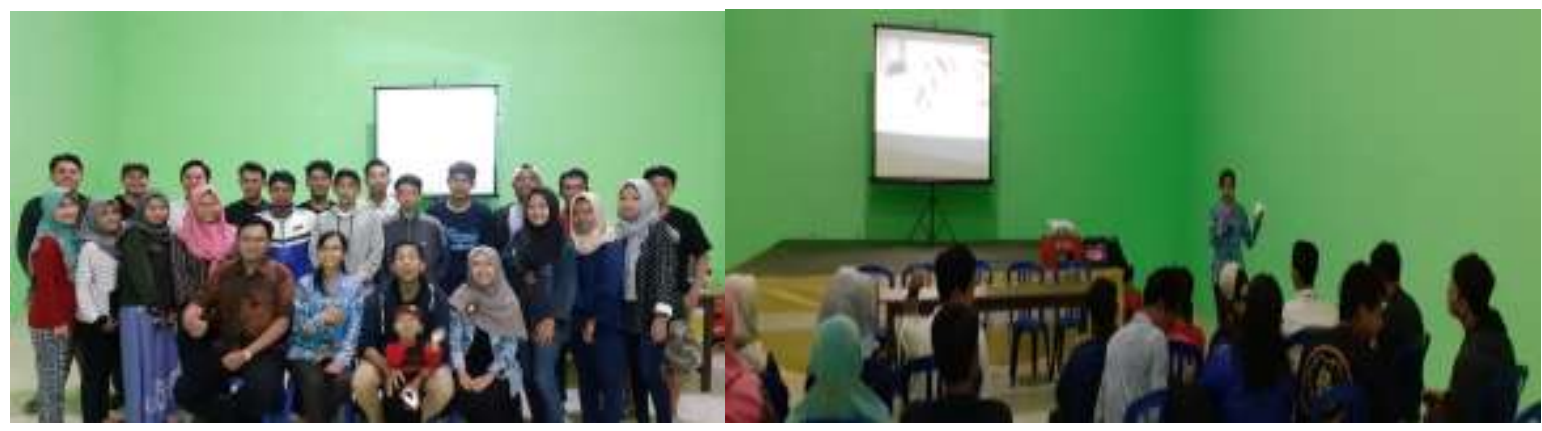

Gambar 2. Pelatihan penciptaan permainan bahasa (doc pribadi)

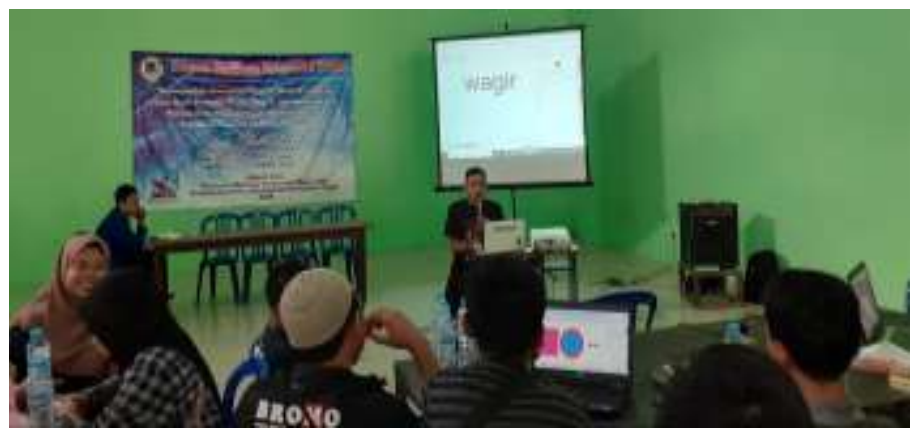

Gambar 3. Pelatihan desain dengan corel draw (doc. Pribadi) 
e. Pelatihan Pemasaran Digital

Marketing merupakan faktor penting kesuksesan sebuah brand. Pelatihan dilakukan untuk membekali kelompok dengan cara-cara atau tipstips berjualan dengan teknik pemasaran digital. Adapun teknik pemasaran digital yang dapat dimanfaatkan adalah media sosial seperti Instagram dan Facebook atau dengan memanfaatkan e-commerce seperti Tokopedia, Shopee, Bukalapak dll. Kegiatan ini dilakukan pada tanggal 19 Mei 2019 yang disampaikan oleh pemateri dari tim
Pengabdi menggandeng praktisi dalam bidang pemasaran digital. Adapun dokumentasi kegiatan dapat dilihat pada Gambar 4.

\section{f) Pendampingan} Rencana Usaha

Pelatihan penyusunan rencana usaha dilakukan untuk memberikan wawasan pengembangan bisnis yang akan dilakukan. Kegiatan dilaksanakan pada tanggal $26 \mathrm{Mei}$ 2019. Adapun dokumentasi kegiatan dapat dilihat pada Gambar 5.
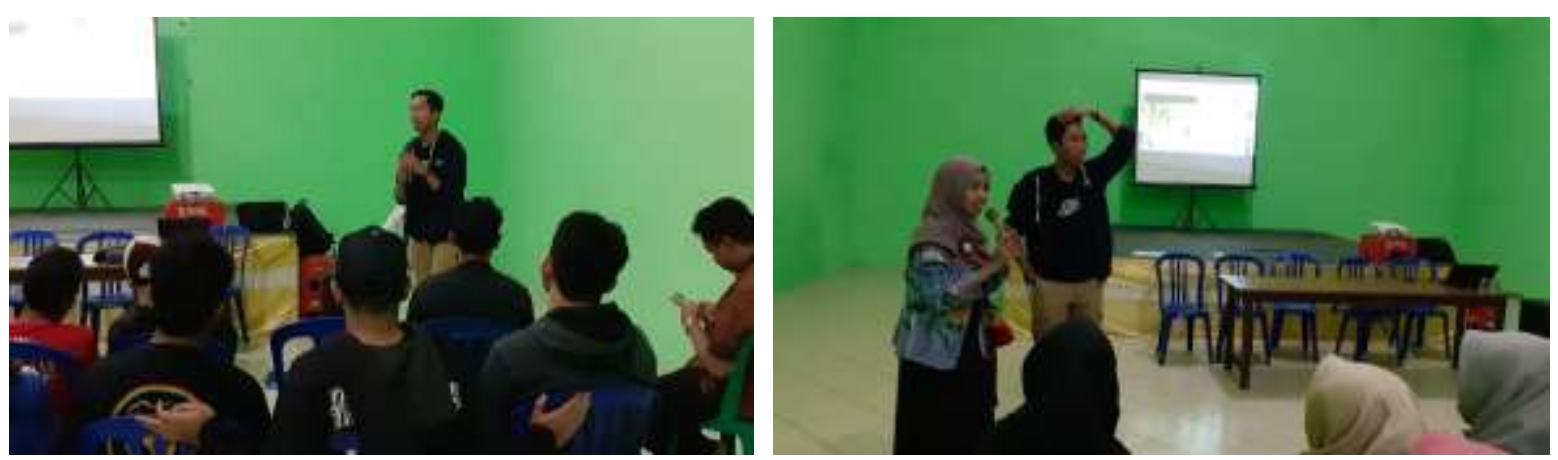

Gambar 4. Pelatihan pemasaran digital (doc. Pribadi)

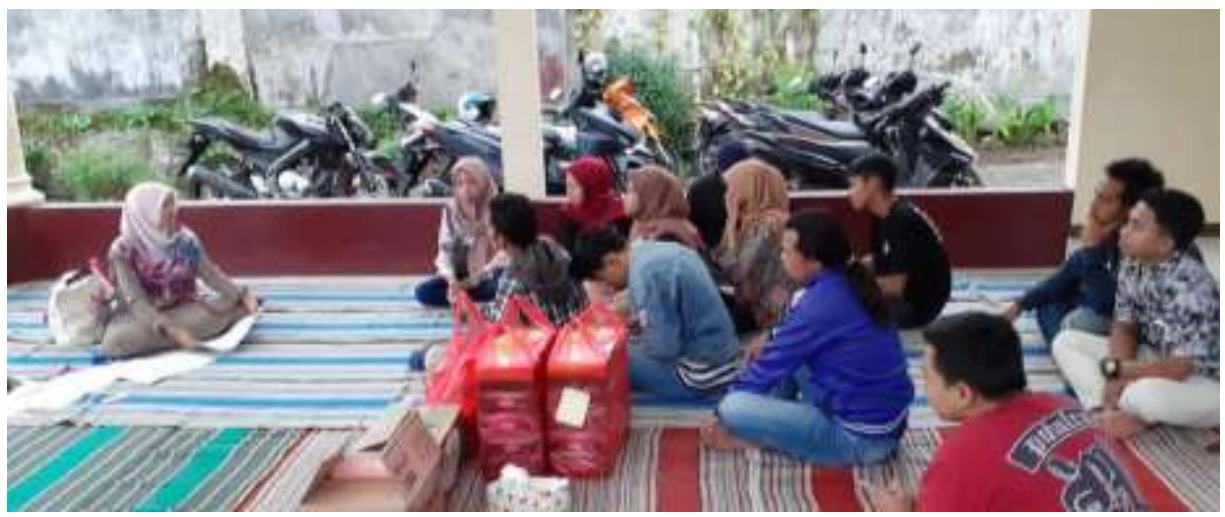

Gambar 5. Kegiatan pendampingan rencana usaha (doc. Pribadi) 


\section{h. Kegiatan serah terima alat penunjang}

Kegiatan serah terima alat penunjang dilaksanakan pada hari Jumat, 28 April
2019 diketahui oleh PLT Kepala Desa Parangargo. Alat penunjang yang diberikan adalah mesin cutting dan mesin press.
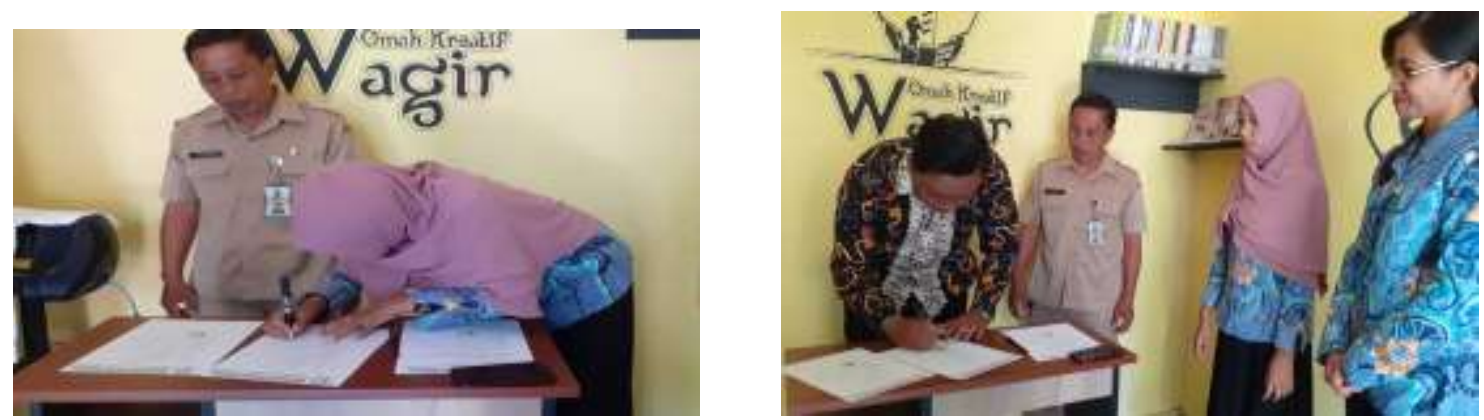

Gambar 6. Kegiatan serah terima alat penunjang (doc. Pribadi)

\section{g) Pelatihan dan Pendampingan Produksi}

Kreativitas menciptakan permainan bahasa yang akan diaplikasikan pada kaos akan menjadi penentu utama keberhasilan

produk tersebut. Selain pendampingan dalam memroduksi kaos juga menjadi hal penting sehingga tercipta produk yang berkualitas.
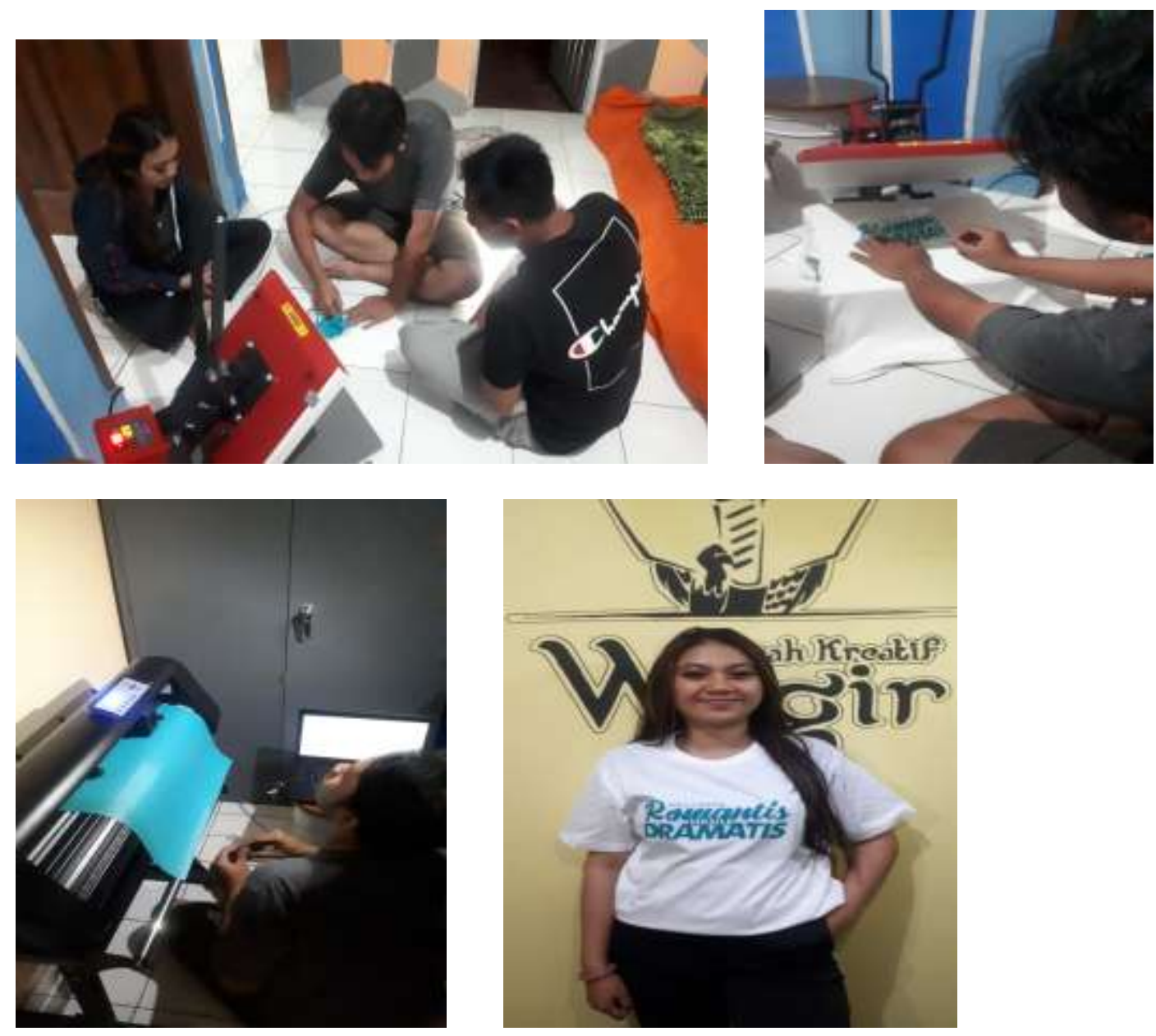

Kingkin: Pemanfaatan Permainan Bahasa Menjadi Produk Usaha Kaos Berbasis Bisnis Kata di Kelompok Karang Taruna Desa Parangargo Kecamatan Wagir Kabupaten Malang untukMendukung EKonomi Kreatif 


\section{PEMBAHASAN}

Pengabdian masyarakat PKM Pemanfaatan Permainan Bahasa Menjadi Produk Usaha Kaos Berbasis Bisnis Kata di Kelompok Karang Taruna Desa Parangargo Kabupaten Malang ini menggunakan model pemberdayaan kepada pemuda/pemudi untuk terlibat dalam industri kreatif khususnya yang berkaitan dengan produksi kata-kata yang akan diaplikasikan di kaos sablon. Permainan bahasa atau yang akrab disebut dengan plesetan merupakan hal yang dekat dengan anak muda. Permainan bahasa dilakukan dengan menggunakan bahasa yang tidak semestinya. Kreativitas menciptakan permainan bahasa dapat dilakukan dengan menerapkan beberapa formula, yaitu permainan angka dan huruf, permainan kata, permainan antar bahasa, malapropisme, slang, wacana indah, silap lidah, dan kreasi wacana.

Permainan bahasa ini oleh pemuda akan diaplikasikan dalam bentuk kaos sablon. Kaos sablon tersebut diproduksi dengan menggunakan alat sablon digital. Beberapa keuntungan menggunakan alat sablon digital adalah mudah, efesien, dan lebih produktif. Selanjutnya, produk kaos yang dihasilkan juga akan dipasarkan secara digital melalui media social, seperti halnya Facebook, Instagram, Line, dsb. yang merupakan teknologi yang sangat dekat dengan kehidupan masyarakat saat ini. Maka, produk kreatifitas anak-anak muda ini diharapkan dapat diminati dan berdaya beli oleh masyarakat, sehingga dapat mendukung salah satu program pemerintah yaitu menciptakan masyarakat ekonomi kreatif.

\section{KESIMPULAN}

Kreatifitas dapat menjadi modal utama dalam meningkatkan perekonomian masyarakat. Salah satu contohnya adalah kreatifitas anak-anak muda karang taruna Parangargo yang mencoba berkreasi dalam permainan bahasa untuk bisnis kaos. Didukung beberapa pelatihan dalam aspek produksi dan manajemen dengan mengaplikasikan teknologi untuk menghasilkan produk kaos serta pemasaran digital melalui media sosial, muda mudi karang taruna ini diharapkan mampu berpartisipasi untuk mengembangkan ekonomi kreatif masyarakat, khususnya di desa Parangargo, kecamatan Wagir, kabupaten Malang.

\section{REFERENSI}

Wijana, I Dewa Putu. 2010. Kartun: Studi Tentang Permainan Bahasa. Yogyakarta: Gadjah Mada University Press. 2018. Apa Ekonomi Kreatif dan Potensi Besar Bagi UKM. (Online), (https://id.wikipedia.org/wiki/Ekonomi_kreat if), diakses 18 Agustus 2018.

2018. Tonggak Baru Ekonomi Kreatif Indonesia.(Online),

(http://www.bekraf.go.id/profil), diakses 18 Agustus 2018.

2018. Profil Dagadu. (Online), (http://www.dagadu.co.id/). Diakses 18 Agustus 2018.

Pengurus Karang Taruna. 2017. Program Kerja Karang Taruna Desa Parangargo. Dokumen, Tidak diterbitkan. 